\title{
Particle flux and food supply to a seamount cold- water coral community (Galicia Bank, NW Spain)
}

\author{
G. C. A. Duineveld*, M. S. S. Lavaleye, E. M. Berghuis \\ Royal Netherlands Insitute for Sea Research, PO Box 59, 1790 AB Den Burg, Texel, The Netherlands
}

\begin{abstract}
In a European effort (Atlantic Coral Ecosystem Study [ACES project]) to determine the key conditions for the occurrence of cold-water corals on the NW Atlantic margin, a coral community on a seamount off NW Spain (Galicia Bank) was studied. Cold-water corals (Lophelia pertusa, Madrepora oculata) grow at a depth of $\sim 800 \mathrm{~m}$ as isolated patches amidst small ripples and larger waves of foraminiferal sand. A 17 mo deployment of a near-bottom sediment trap revealed a large seasonal and annual variability in the flux of phytodetritus and carbon. The daily carbon flux in the first $5 \mathrm{mo}$ of 2000 was on average $37 \mathrm{mgC} \mathrm{m}^{-2}$, and in the first $5 \mathrm{mo}$ of $200117 \mathrm{mg} \mathrm{C} \mathrm{m}^{-2}$. Quantities of faecal pellets and swimmers (copepods, amphipods) were also highly variable. A comparison between the daily carbon flux and the sediment carbon oxidation rate calculated from in situ community oxygen consumption (SCOC), i.e. 17 versus $7 \mathrm{mg} \mathrm{C} \mathrm{m}^{-2} \mathrm{~d}^{-1}$ respectively, indicated that a surplus of carbon is not oxidised by the sediment community. We argue that the strong tidal currents (max. $30 \mathrm{~cm} \mathrm{~s}^{-1}$ ) and the mobile sediment lead to winnowing of the sediment and to near-bed transport of the organic material. The low biomass of the benthic community and the domination of filterfeeders support our arguments. By means of analyses of stable isotopes $\left(\delta^{15} \mathrm{~N}, \delta^{13} \mathrm{C}\right)$ we attempted to find potential food items of the cold-water corals among the particles collected in the sediment trap. The difference between the $\delta^{15} \mathrm{~N}$ signatures of coral tissue $(9.5 \%)$ and phytodetritus $(2.2 \%)$ was $>1$ trophic level, indicating that sinking algae are not the sole food source. The $\delta^{15} \mathrm{~N}$ signatures of swimmers caught in the trap, $\sim 10 \%$, were on the other hand in the same range as those of the corals. A mixed diet of animals and algae could be one explanation for the observed $\delta^{15} \mathrm{~N}$ of corals. The $\delta^{13} \mathrm{C}$ value of the coral tissue, $-20.55 \%$, excludes a food source consisting of bacteria supported by methane seepage, as suggested by earlier studies.
\end{abstract}

KEY WORDS: Cold-water corals $\cdot$ Particle flux $\cdot$ Stable isotopes $\cdot$ Bottom landers

Resale or republication not permitted without written consent of the publisher

\section{INTRODUCTION}

It has been known for some time (LeDanois 1948) that the colonial deep-water or 'cold' coral Lophelia pertusa is a common species on the NE Atlantic continental slope. New investigations have shown that $L$. pertusa occurs along virtually the whole NE Atlantic continental margin and rims of the Rockall Bank and Faroes plateau (Zibrowius 1980, Frederiksen et al. 1992, Rogers 1999). In some areas, populations of $L$. pertusa together with Madrepora oculata form large reef-like structures some kilometres in length, for example, along the Sula ridge off Norway (Mortensen et al. 1995, 2001, Freiwald et al. 2002). More often, however, L. pertusa occurs in patches on top of topographic highs ('mounds') of smaller dimensions (Wilson 1979, Mortensen et al. 2001). Living in thickets or in a reef, $L$. pertusa forms an important catalyst for biodiversity on continental margins as a multitude of other organisms live in association with this coral. Recent studies have suggested that levels of biodiversity in $L$. pertusa communities are similar to those of communities in shallow-water tropical reefs (Jensen \& Frederiksen 1992, Rogers 1999). Because of the shelter they provide to many abundant life forms, $L$. pertusa communities also comprise rich fishing grounds. With the depletion of shallow-water fish stocks and the improvement of technologies, fisheries are now becom- 
ing a serious threat to L. pertusa in many areas (Mortensen et al. 1995, Fosså et al. 2002).

The factors determining the formation of deep-coral coenosis are largely unknown. Salinity and temperature seem to play a role (Freiwald 2003), but also turbulence and its effect on food supply are proposed as controlling factors (Mortensen et al. 2001). Frederiksen et al. (1992), for instance, linked the distribution of Lophelia pertusa on the Faroes plateau with a zone of intensified mixing resulting from the interaction between internal waves and bottom topography. Also, the tendency of $L$. pertusa to occur on topographic highs points to the importance of turbulence (Masson et al. 2003). Hovland (1990) on the other hand suggested that a relation exists between cold-water corals and seepage of hydrocarbons, implying a direct or indirect role of chemo-autotrophic bacteria in coral feeding (Hovland \& Thomsen 1997). This shows that information on the food source of L. pertusa is critical to evaluate which environmental factors are relevant for its occurrence. So far little is known on this subject. Underwater observations have shown polyps capturing zooplankton organisms, while aquarium studies indicate that $L$. pertusa ulitises dead organic matter as well (Mortensen et al. 2001).

Understanding the distribution of Lophelia pertusa requires insight into both the coral's biology and the ambient conditions (e.g. particle flux, currents) required for its growth and recruitment. The combination of such measurements in deep coral habitats is sparse. During the EU-funded 'Atlantic Coral Ecosystem Study' program (ACES; A. Freiwald: www.geol. uni-erlangen.de/pal/proj/aces), a comparative assessment was made of biological and environmental features of coral biotopes along the whole NE Atlantic margin. Herein, we present observations and measurements made during ACES in a cold-water coral community on top of Galicia Bank (NW Spain). The objectives of the study were (1) to describe the general characteristics of the local L. pertusa and Madrepora oculata habitat by means of underwater video, current-meter and CTD measurements; (2) to obtain insight into the magnitude and quality (pigment content) of the particle and carbon flux to the coral community, and into the proportion of the carbon input that is oxidised in the coral habitat using in situ sediment oxygen-consumption measurements (Smith et al. 2001); (3) to explore the trophic relationship between settling particles and the cold-water coral by analysis of $\delta^{15} \mathrm{~N}$ signatures (Michener \& Schell 1994). The possible role of chemoautotrophic bacteria as a food source of cold-water corals (Hovland \& Thomsen 1997) was investigated by means of the $\delta^{13} \mathrm{C}$ signature of the coral tissue.

\section{MATERIALS AND METHODS}

Study area. Galicia Bank is situated $\sim 125$ nautical miles (n miles) offshore the coast of NW Spain, and is separated from the Iberian continental margin by a 3000 m deep channel (Fig. 1). Although Lophelia pertusa is known to occur in many parts of the Iberian continental margin (Zibrowius 1980), no published records exist for Galicia Bank. The first time we encountered live L. pertusa on Galicia Bank was during a benthic survey in 1998 in the framework of the OMEX-II (Ocean Margin Exchange) programme (Lavaleye et al. 2002). The data on the macrofauna collected from Galicia Bank on that cruise were analysed and published by
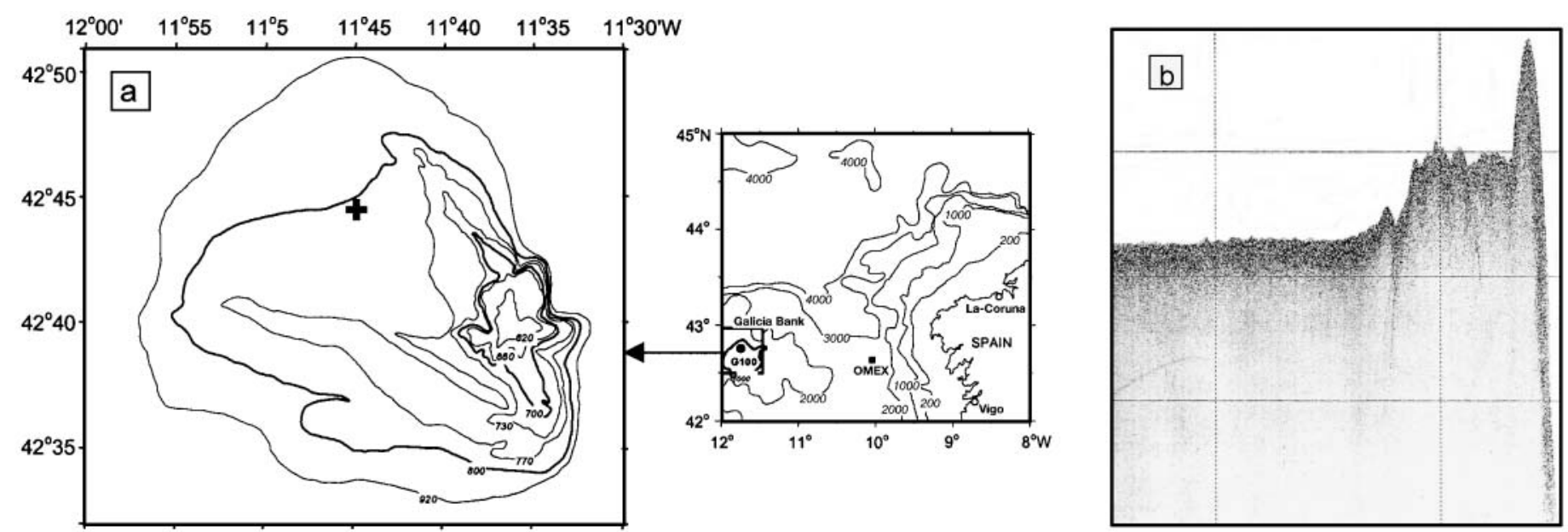

Fig. 1. (a) Map showing position of Galicia Bank (right) and detailed bathymetry (left); (†) position of the bottom landers. (b) Echosounder profile ( $3.5 \mathrm{kHz})$ across Galicia bank showing steep peaks to east and relative flat plain to west 

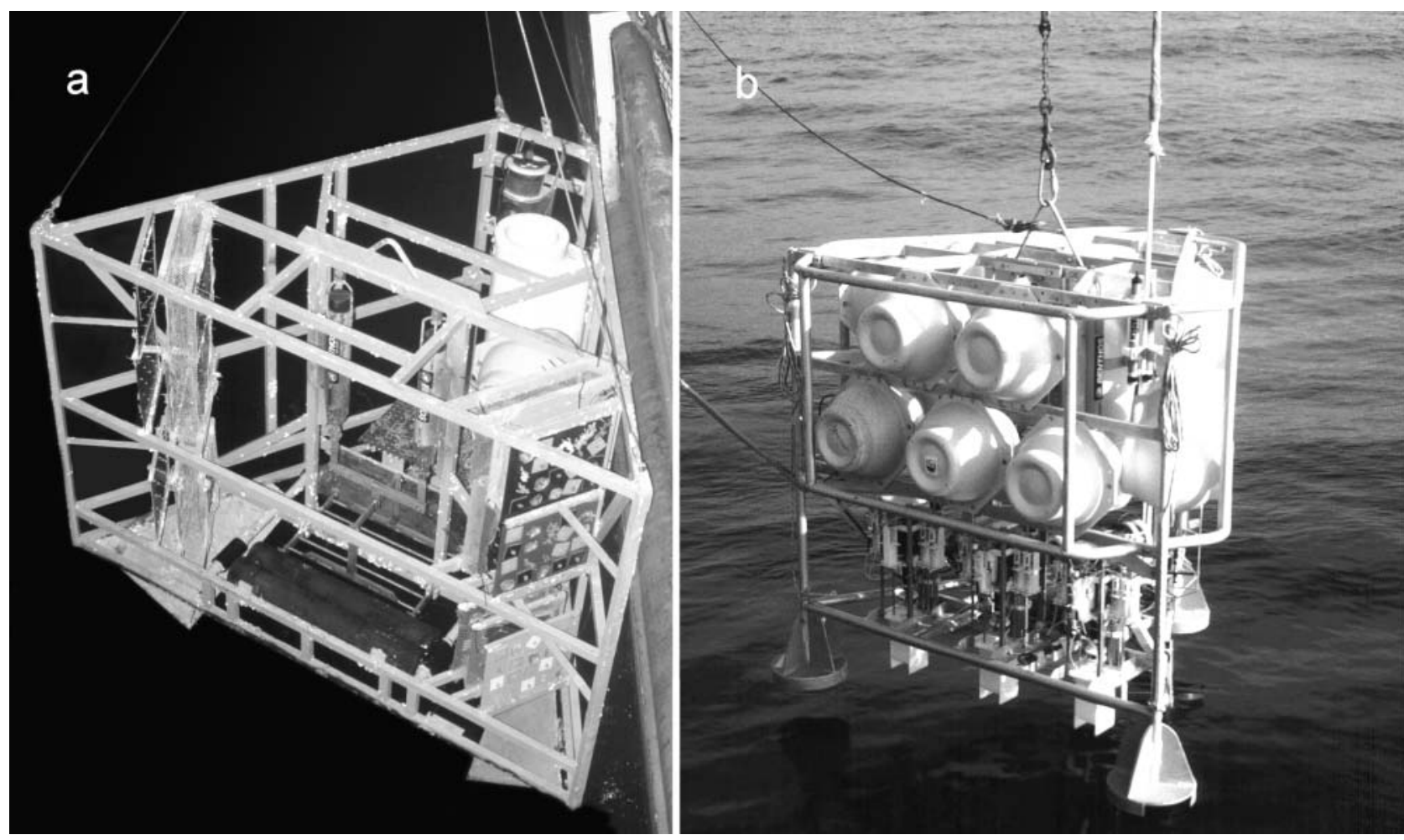

Fig. 2. The 2 free-falling bottom landers used in this study. (a) Recruitment lander showing panels with artificial substrates and PPS4/3 sediment trap; (b) ALBEX (Autonomous Lander for Biological Experiments) lander with 3 incubation chambers for in situ measurement of sediment community oxygen consumption

Flach et al. (2002). The data presented in this paper were collected at intervals between June 1998 and June 2001 with 2 bottom landers deployed at Stn G100 $\left(42^{\circ} 44.8^{\prime} \mathrm{N}, 11^{\circ} 45.8^{\prime} \mathrm{E}\right)$ at $770 \mathrm{~m}$ depth.

Bottom lander measurements. We deployed 2 types of free-falling bottom landers on the Galicia Bank. Of these, 1 was a recruitment lander for studying settlement rates of corals and associated organisms. The recruitment lander (Fig. 2a) consists of a triangular frame with 2 acoustic releasers and a single $300 \mathrm{~kg}$ ballast weight. A package with 16 Benthos $^{\mathrm{TM}}$ flotation spheres is connected to the top of the frame. Besides a series of artificial substrates for colonisation experiments, the recruitment lander is equipped with a 12-cup Technicap ${ }^{\mathrm{TM}}$ PPS4/3 sediment trap, with an opening $3 \mathrm{~m}$ above the bottom and a time-lapse video. By means of a fluorometer (Seapoint ${ }^{\mathrm{TM}}$ ) built into the trap, we could make high-resolution measurements on the rain of fluorescent particles passing through the trap funnel. During the period January to June 2001, an acoustic current meter (FSI Inc.) was attached to the recruitment lander $1 \mathrm{~m}$ above the bottom. Measurements of current speed were made every 20 min.

The second lander was the ALBEX (Autonomous Lander for Biological Experiments) chamber lander
(Fig. 2b) for in situ measurement of sediment community oxygen consumption (SCOC), which is an estimate of the amount of labile carbon mineralised by the sediment community and, hence, of the carbon input into the community (Smith et al. 2001). The ALBEX lander has 3 independent incubation chambers $(12 \times 12 \mathrm{~cm})$ that are hydraulically inserted into the sediment at programmed times. Each chamber has a stirrer and an optical oxygen sensor (optode) to ensure stability during long-term deployment. The optode has a ruthenium-based fluorophore manufactured by Dr. B. Camerman and Professor E. Vander Donckt (Université Libre de Bruxelles). The pressure-resistant titanium casing and electronics of the optode were developed and built by H. Franken and J. van Heerwaarden at the Royal Netherlands Institute for Sea Research (NIOZ); 4 blue LEDs (light emitting diodes) with an emission maximum of $450 \mathrm{~nm}$ are used as excitation source. The current through the LEDs is sine-wave modulated at $112 \mathrm{kHz}$ using a crystal oscillator and a bandpass filter. The emission at wavelengths higher than $500 \mathrm{~nm}$ is cut off by a glass filter. The fluorescence signal is filtered by a long-pass glass filter and detected by a photodiode. A second photodiode is used to measure the excitation signal as a reference source. 
The signals from both photodiodes are first amplified, then clipped and changed to a logic level with a comparator. The phase difference between these signals is obtained with a phase discriminator (non-exclusive or gate) and a low-pass filter. The phase signal is used to calculate the oxygen concentration. $\mathrm{SCOC}\left(\mathrm{mmolO}_{2}\right.$ $\mathrm{m}^{-2} \mathrm{~d}^{-1}$ ) was calculated from the decrease in the oxygen concentration in the headspace over time. The output of the optodes was calibrated against $\mathrm{O}_{2}$ concentration in near-bottom water samples determined with the Winkler method.

Pigment analysis. The cups of the sediment trap were filled with a solution of $2 \%$ glutaraldehyde and filtered seawater to prevent degradation of algal pigments, as recommended by Meyerhoefer (1994). The contents of the cups were split in 4 or 8 parts (depending on the quantity) with a Folsom splitter and washed over $2 \mu \mathrm{m}$ cellulose-acetate filters. The splits were photographed and examined under a stereomicroscope. Faecal pellets and organisms (swimmers, benthos) were classified and counted, and the latter were conserved. Finally the splits were freeze-dried. Mass fluxes were calculated from the dry weight. In 1 split from each cup, we determined concentrations of chlorophyll $a$, its derivates (phaeophorbides, phaeophytines) and principal carotenoids with reversephase HPLC. For the analysis and quantification of the pigments we used the methods described in Witbaard et al. (2000).

Stable isotopes and carbon. Samples of trap material were only analysed for their $\delta^{15} \mathrm{~N}$ signature because of a possible effect of the preservative glutaraldehyde on $\delta^{13} \mathrm{C}$. Moreover, $\delta^{15} \mathrm{~N}$ has more discriminative power in trophic analysis because of the $3 \%$ enrichment per trophic level in comparison to the $\sim 1 \%$ in terms of $\delta^{13} \mathrm{C}$ (Michener \& Schell 1994). Fresh coral tissue was also analysed with respect to $\delta^{13} \mathrm{C}$ in order to investigate the proposed relationship between corals and the seepage of light hydrocarbons (methane; Hovland \& Thomsen 1997). The technique used for the analysis was elemental analyserisotope ratio mass spectrometry (EA-IRMS). The analyses were performed by Iso-Analytical Ltd. The $\delta^{13} \mathrm{C}$ and $\delta^{15} \mathrm{~N}$ values reported here are defined as

$$
\delta \mathrm{X}=\left[\left(\mathrm{R}_{\text {sample }}-\mathrm{R}_{\text {std }}\right) / \mathrm{R}_{\text {std }}\right] \times 1000
$$

where $\mathrm{X}={ }^{13} \mathrm{C}$ or ${ }^{15} \mathrm{~N}, \mathrm{R}={ }^{13} \mathrm{C} /{ }^{12} \mathrm{C}$ or ${ }^{15} \mathrm{~N} /{ }^{14} \mathrm{~N}$ and $\operatorname{std}=$ standard.

Between 20 and $25 \%$ of the samples were analysed in duplicate for quality control. The reference material used in the analysis of the samples was chosen so that it complemented the type of sample being analysed. For ani- mal-tissue samples, the reference used was NBS $1577 \mathrm{a}$ (bovine liver) with a $\delta^{13} \mathrm{C}$ value of $-21.68 \%$ versus V-PDB and a $\delta^{15} \mathrm{~N}$ value of $7.25 \%$ versus air. NBS $1577 \mathrm{a}$ is traceable to IAEA-CH-6 (sucrose) with an accepted $\delta^{13} \mathrm{C}$ value of $-10.40 \%$ versus $\mathrm{V}-\mathrm{PDB}$, and IAEA-N-1 (ammonium sulphate) with an accepted $\delta^{15} \mathrm{~N}$ value of $0.40 \%$ versus air. For sediment samples, the reference used was Iso-Analytical flour with a $\delta^{15} \mathrm{~N}$ value of $2.55 \%$ versus air. The flour is traceable to IAEA-N-1 (ammonium sulphate) with an accepted $\delta^{15} \mathrm{~N}$ value of $0.40 \%$ versus air.

The organic carbon content of the trap samples was measured with a Carlo Erba elemental analyser using the procedure of Epping et al. (2002).

\section{RESULTS}

\section{Galicia Bank - topography, currents and temperature}

The upper part of Galicia Bank is relatively flat, except for the easternmost part which consists of a series of steep peaks along the precipitous eastern slope of the bank (Fig. 1b). The flat part is covered by a thick layer of planktonic foraminifera ooze with a median grain size of $\sim 190 \mu \mathrm{m}$ and only $0.2 \%$ organic carbon (Flach et al. 2002). The surface of the sediment consists of numerous small current ripples and occasional megaripples of $\sim 50 \mathrm{~cm}$ height, indicating mobile sediment and high current velocities. Coral thickets occur as isolated patches near or on top of the megaripples (Fig. 3). The eastern peak of the bank consists of barren basalt rock with hardly any corals or other life-

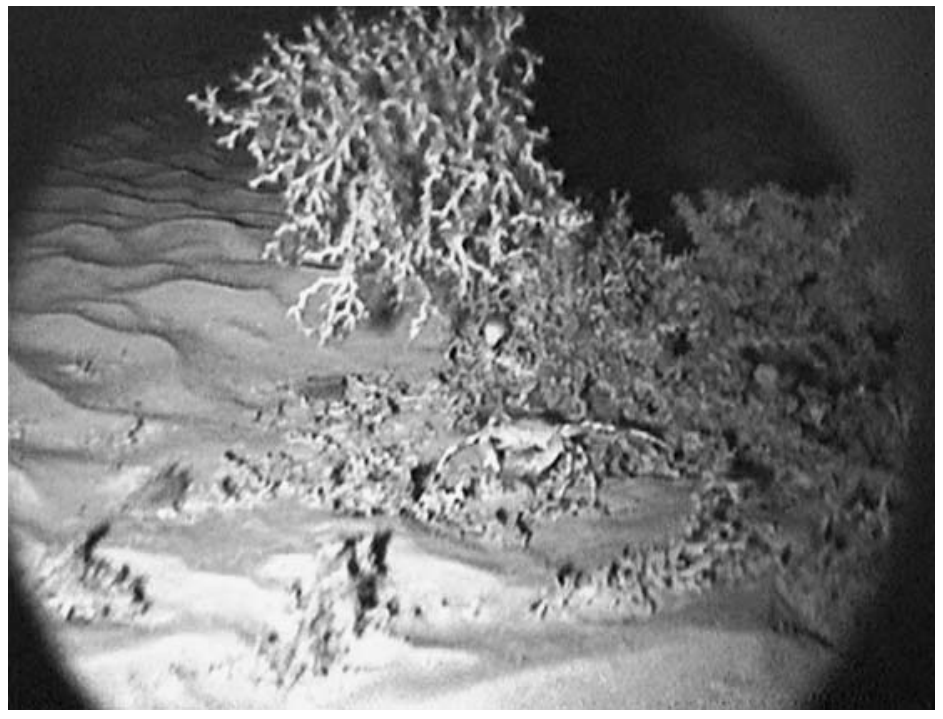

Fig. 3. Lophelia pertusa. Underwater video photo on Galicia Bank showing a coral colony amidst mobile sediment with current ripples 


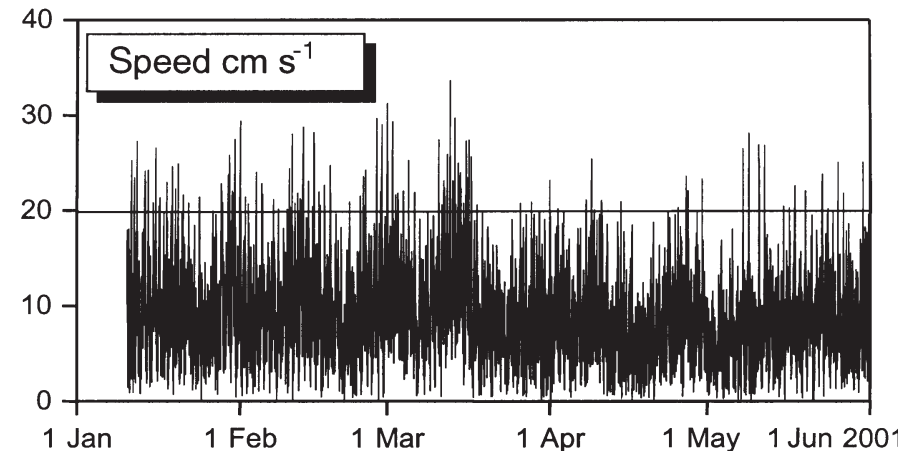

Fig. 4. Current speed $\left(\mathrm{cm} \mathrm{s}^{-1}\right)$ at $1 \mathrm{~m}$ height above bottom during period January to May 2001

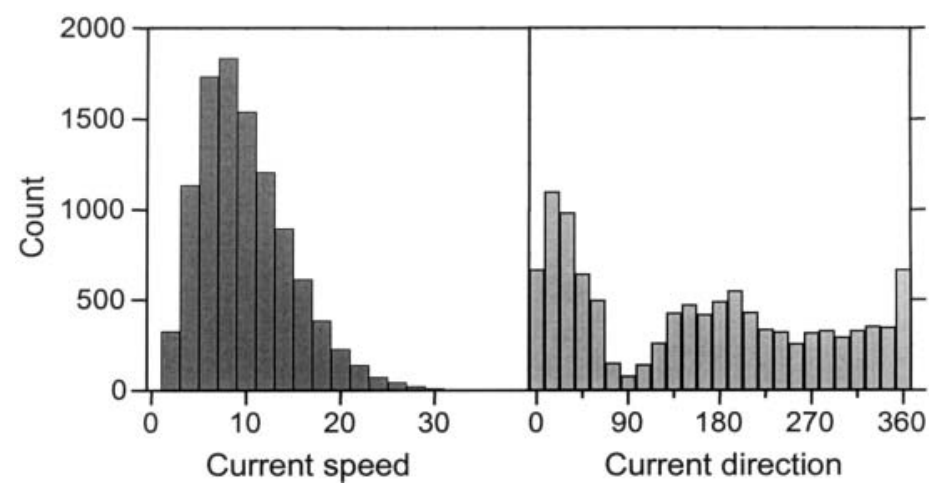

Fig. 5. Frequency distribution of current speeds $\left(\mathrm{cm} \mathrm{s}^{-1}\right)$ and current direction (in ${ }^{\circ}$ ) during period January to May 2001

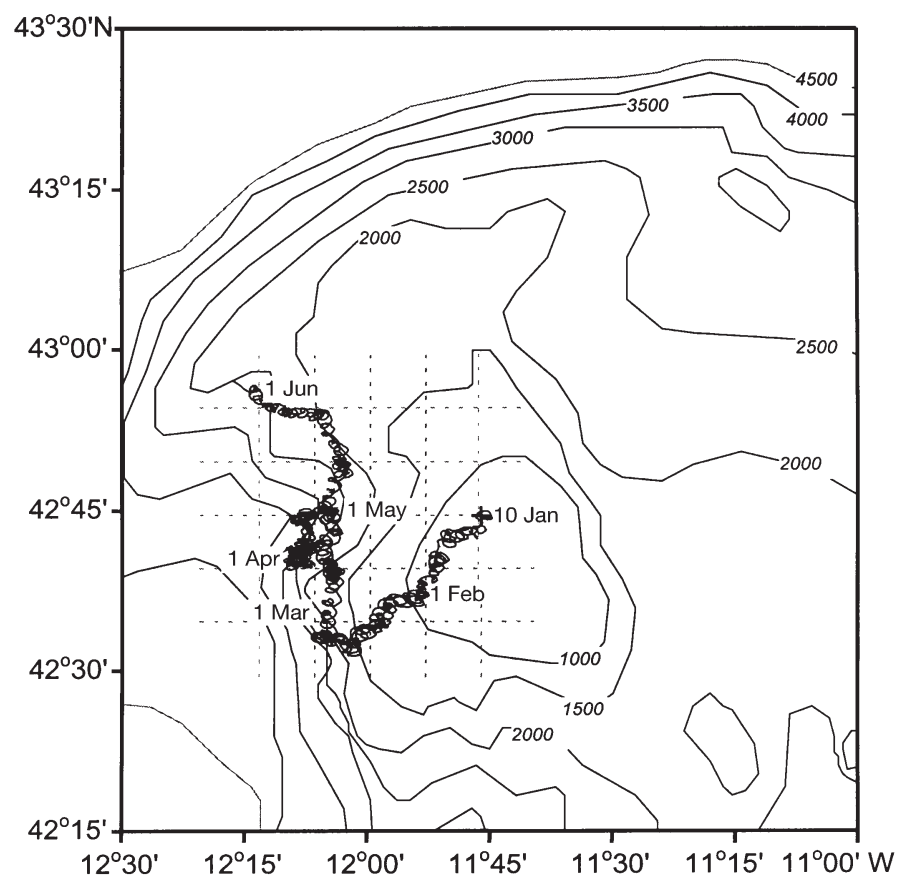

Fig. 6. Progressive vector plot of currents in the period January to May 2001 forms. The transition zone between the sandy plain and the barren peaks is densely covered by mobile crinoids.

The current speed at $1 \mathrm{~m}$ above the seafloor ranged between $<5$ and $30 \mathrm{~cm} \mathrm{~s}^{-1}$, with a median of $8 \mathrm{~cm} \mathrm{~s}^{-1}$ (Fig. 4). During the period January to mid-March 2001, the current speed was frequently $>25 \mathrm{~cm} \mathrm{~s}^{-1}$. Northerly and southerly currents were predominant (Fig. 5). In Fig. 6 we have superimposed a progressive vector plot of the currents on a map of Galicia Bank. This shows that residual current directions at the lander position were variable during deployment, i.e. southwest during the first $1.5 \mathrm{mo}$ and mainly northwards during the other months, with an intermediate period between April and May with relatively little net horizontal displacement. Assuming that current and direction are constant along the trajectory in Fig. 6, a particle arriving at Stn G100 would be transported off Galicia Bank within roughly 1 mo.

The bottom-water temperature during deployment varied between 10.7 and $11.7^{\circ} \mathrm{C}$ (mean 11.2; Fig. 7). These temperatures are in the upper part of the range in which Lophelia pertusa is known to occur, i.e. 4 to $12^{\circ} \mathrm{C}$ (Rogers 1999). Excursions of plus and minus $\sim 0.5^{\circ} \mathrm{C}$, even within $12 \mathrm{~h}$, occurred without any obvious regularity. In Fig. 8 we have combined temperature and salinity depth profiles from Stn G100 with those from a nearby station $10 \mathrm{n}$ miles east of G100 in the deep channel between Galicia Bank and the slope. It can be seen that the top of Galicia Bank (700 to $900 \mathrm{~m}$ depth) is covered by the salinity maximum typical of the Mediterranean Sea outflow water (van Aken 2000, Freiwald 2003).

\section{Particle flux}

The dry mass and pigment fluxes at Stn G100 during the periods January to October 2000 and January to May 2001 are depicted in Fig. 9a,b. Because of logistic

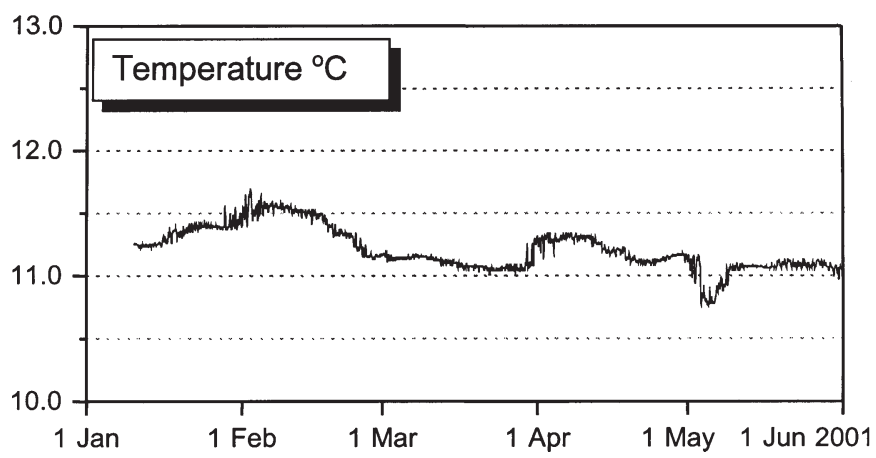

Fig. 7. Bottom-water temperature at $1 \mathrm{~m}$ above bottom during January to May 2001 


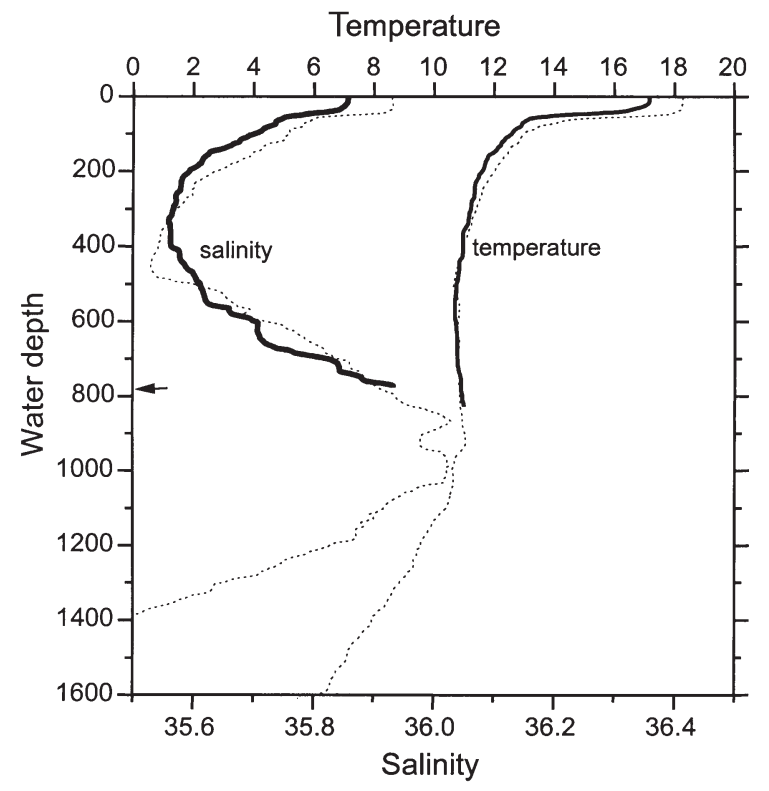

Fig. 8. CTD profiles of water column at study site (Galicia Bank $770 \mathrm{~m}$, continuous lines) and at deep site $10 \mathrm{n}$ miles to the east (dotted lines). Note salinity maximum typical of Mediterranean outflow water constraints we have no data for November and December 2000. The total mass fluxes in the specific periods were $307 \mathrm{~g} \mathrm{~m}^{-2}$ (14 January to 30 May 2000), $16 \mathrm{~g} \mathrm{~m}^{-2}$ (11 June to 27 October 2000) and $343 \mathrm{~g} \mathrm{~m}^{-2}$ (16 January to 28 May 2001). Outliers were the samples from January 2000 with $17 \mathrm{~g} \mathrm{~m}^{-2} \mathrm{~d}^{-1}$, and early February 2001 with $11 \mathrm{~g} \mathrm{~m}^{-2} \mathrm{~d}^{-1}$. The total mass flux in the year 2000 amounts to $331 \mathrm{~g}$ when the extreme January value is included, or $135 \mathrm{~g} \mathrm{~m}^{-2}$ when it is excluded. These values include an estimate for the missing data for November and December 2000. This estimate was calculated from the average mass flux in autumn 2000. In both years the trap collected highest mass fluxes in winter (Fig. 9a).

Total fluxes of organic carbon ( $\mathrm{C}$ org) over the 3 consecutive periods were 5.1 (14 January to 30 May 2000), 0.3 (11 June to 27 October 2000) and $2.3 \mathrm{~g} \mathrm{~m}^{-2}$ (16 January to 28 May 2001). The minimal C org flux over the year 2000 was $5.4 \mathrm{~g} \mathrm{~m}^{-2}$. The highest daily carbon fluxes, i.e. 40 to $95 \mathrm{mg} \mathrm{C} \mathrm{m}^{-2} \mathrm{~d}^{-1}$, were observed from early March 2000 to the end of May 2000. The C/N ratios of the trap material varied between 6.6 and 9.7. The highest ratio belonged to the sample collected

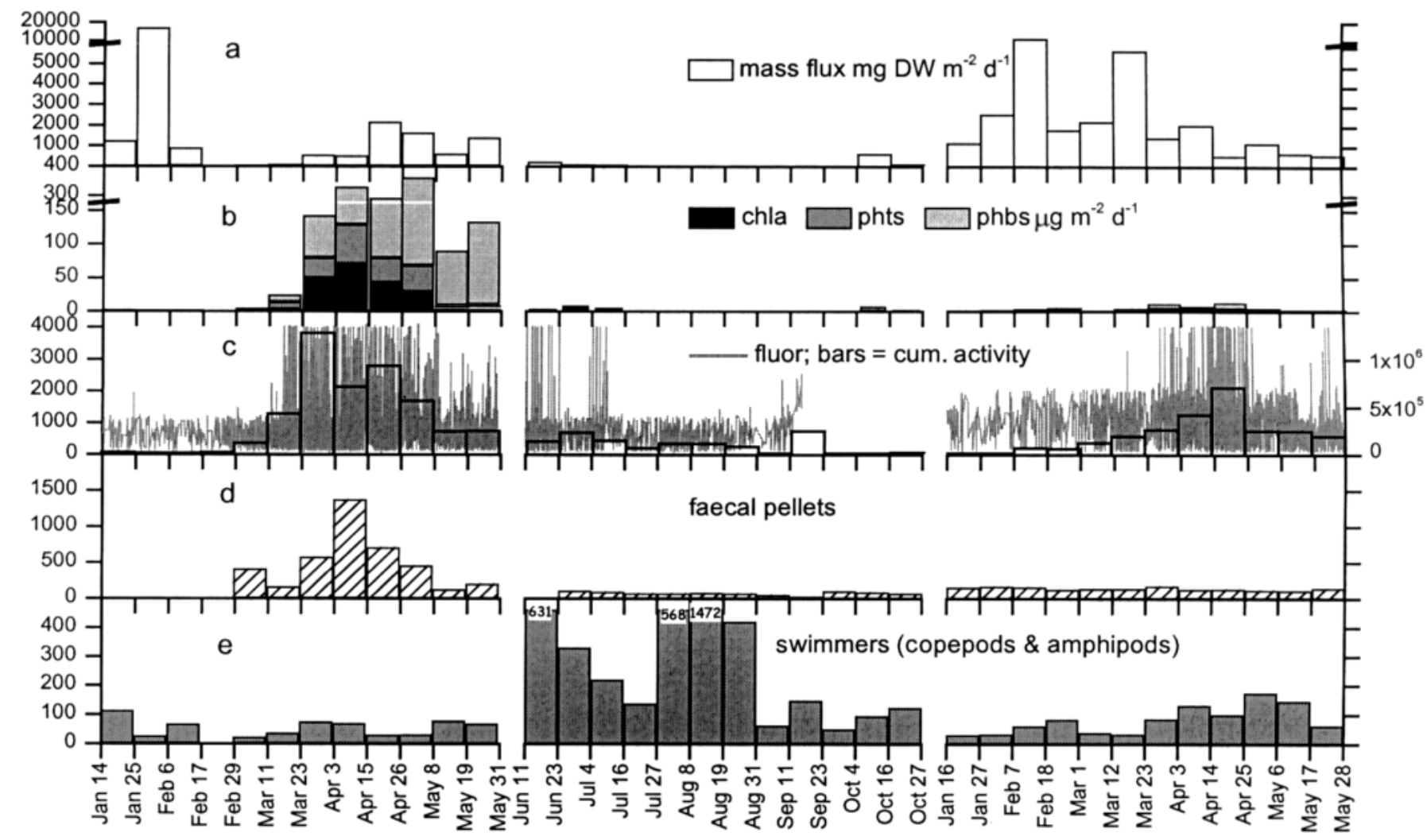

Fig. 9. Combined results of 17 mo deployment (January 2000 to May 2001) of near-bottom sediment trap (3 m above bottom) in coral community on Galicia Bank. Exposure time of the sediment-trap cups was $11 \mathrm{~d}$. (a) Dry weight (mass) flux; (b) flux of chloropigments chlorophyll a (chla), phaeophytins (phts), phaeophorbides (phbs); (c) fluorescence (fluor) record of chlorophyllous particles passing through trap opening and cumulative activity during $11 \mathrm{~d}$ periods; (d) number of faecal pellets per cup (11 d period); (e) number of swimmers (copepods, amphipods) per cup (11 d period) 
during the peak mass flux in early February 2000 and the lowest ratio to the sample at the beginning of the phytodetritus pulse in early April 2000.

The flux pattern of chlorophyll $a$ and phaeopigments is shown in Fig. 9b. In spring 2000 there was a period with distinctly enhanced pigment flux that lasted for about 2 mo. Although the mass flux increased during this period, the overall relation between mass fluxes and fluxes of fresh phytopigments is weak. The composition and age of the phytodetritus gradually changed during the spring peak in 2000. The first samples in this period, i.e. the samples collected from 23 March to 3 April, had the highest ratio chlorophyll a:

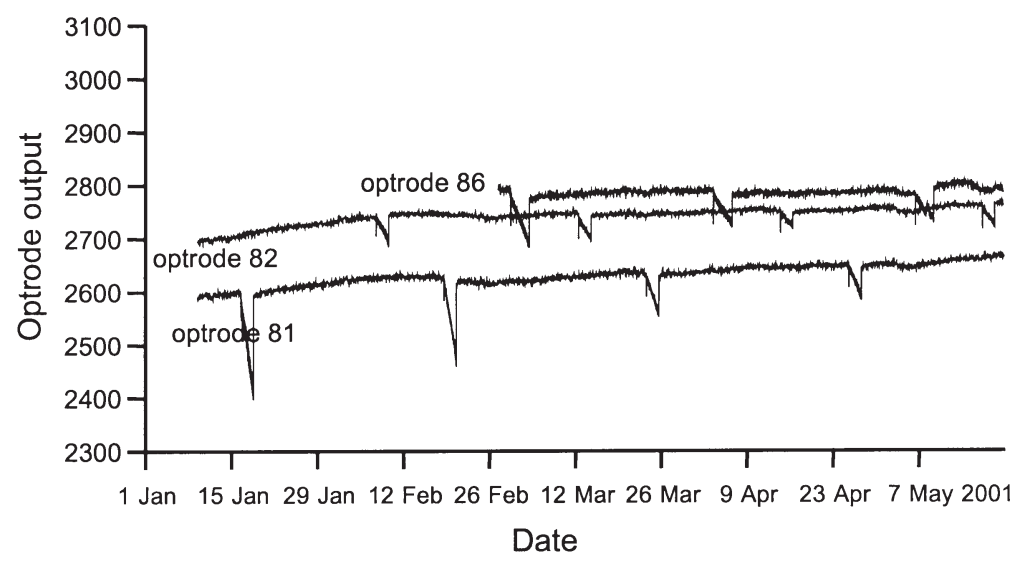

Fig. 10. Output of oxygen sensors (optodes) in 3 incubation chambers of the ALBEX lander during deployment at Galicia Bank from January to May 2001. Depressions in line $=3 \mathrm{~d}$ incubation periods phaeopigments, viz. 0.3. The dominant accessory pigment at this time was 19' hexanoloxyfucoxanthin, indicative for algae belonging to the prymnesiophytes (Jeffrey \& Vesk 1997). During the course of the pulse the ratio decreased to much lower values, e.g. 0.08 on 26 April, and alloxanthin (cryptophytes) became the prominent carotenoid. This change coincided with a distinct increase in the number of (salp) faecal pellets in the samples (Fig. 9d). Analysis of individual salp faecal pellets showed that these were the major source of the alloxanthin. At no time did we find evidence for high proportions of diatoms in the form of their marker pigments fucoxanthin and diadinoxanthin. During the remaining part of the year 2000, both mass and chloropigment fluxes were low. The sum of chloropyllous pigments (chlorophyll $a$ and derivates) over the period January to October 2000 was $\sim 21 \mathrm{mg} \mathrm{m}^{-2}$, with $98 \%$ of this amount collected in the spring peak (March to May). It is evident from Fig. 9b that the pigment flux in spring 2001 was much lower than in the preceding year, by a factor of 20, and no evidence of salp faeces was found. Prominent accessory pigments at the time of the highest chlorophyll a flux in spring 2001 were alloxanthin and zeaxanthin in combination with chlorophyll $b$, pointing to a mixture of algae.

The record of the fluorometer in the funnel of the sediment trap is shown in Fig. 9c in combination with the cumulative activity over the $11 \mathrm{~d}$ periods (bars in Fig. 9c). In mid-March 2000 fluorometric activity showed a sudden increase coinciding with the first appearance of chlorophyll $a$ in the trap samples. This was followed by a period with frequent and high fluorometric activity which lasted for about $4 \mathrm{wk}$. During this time, the highest amounts of chlorophyllous pigments entered the trap. Enhanced fluorometric activity was furthermore recorded in mid-June and early July 2000, but cumulative activity was low and so were

the chlorophyll a levels in the samples (Fig. 9b,c). In 2001 the input of fluorescent (chlorophyllous) particles started at approximately the same time as in 2000, but with a more gradual build-up. Neither cumulative activity nor the phytopigment levels reached the same levels as in the previous spring of 2000. The difference, which is apparent in the quantitative relation between cumulative fluorometric activity and chloropigment fluxes in the 2 spring records (Fig. 9b,c), was mainly due to electronic clipping of the fluorometric signal.

In summer 2000 we found a surprisingly high number of swimmers in the sediment trap (Fig. 9e). The majority of these were calanoid copepods, many with eggs. Gammarid amphipods ranked second in abundance. Other less abundant organisms were the amphipod Phronima sp., chaetognaths and young stages of polychaetes and ophiuroids.

\section{Oxygen consumption of sediment community}

In the period January to May 2001, a total of 11 incubations were conducted in the incubation chambers of the ALBEX lander. Fig. 10 illustrates the optode output during this period. The in situ sediment community oxygen consumption (SCOC) rates of individual measurements varied between 0.5 and $1.5 \mathrm{mmolO}_{2} \mathrm{~m}^{-2} \mathrm{~d}^{-1}$. Monthly averages differed only slightly, i.e. between 0.6 and $0.8 \mathrm{mmolO}_{2} \mathrm{~m}^{-2} \mathrm{~d}^{-1}$. The overall average was $0.7 \mathrm{mmolO}_{2} \mathrm{~m}^{-2} \mathrm{~d}^{-1}$, which is equivalent to $7.1 \mathrm{mgC}$ $\mathrm{m}^{-2} \mathrm{~d}^{-1}$ or $2.6 \mathrm{~g} \mathrm{C} \mathrm{m}^{-2} \mathrm{yr}^{-1}$. These in situ rates are comparable to those we obtained in July 1997 at the same station during shipboard incubations of 2 intact $30 \mathrm{~cm}$ diameter boxcore samples at bottom temperature $\left(11^{\circ} \mathrm{C}\right)$. Oxygen consumption rates in these cores measured over a period of $12 \mathrm{~h}$ were 0.9 and $1.2 \mathrm{mmolO}_{2}$ $\mathrm{m}^{-2} \mathrm{~d}^{-1}$ 


\section{Stable isotopes}

The difference in the ${ }^{15} \mathrm{~N}$ and ${ }^{13} \mathrm{C}$ stable isotope composition of the coral tissue between years was small and not significant (Mann-Whitney $U$-test, $\mathrm{p}>0.05$ ) for both Lophelia pertusa and Madrepora oculata. Pooling the results per species yielded the following mean $( \pm \mathrm{SD})$ for $L$. pertusa tissue: $\delta^{15} \mathrm{~N}=9.31 \pm 0.46$ and $\delta^{13} \mathrm{C}=-21.21 \pm 0.27(\mathrm{n}=16)$. Values for $M$. oculata were comparable: $\delta^{15} \mathrm{~N}=9.52 \pm 0.23$ and $\delta^{13} \mathrm{C}=-20.55$ $\pm 0.50(\mathrm{n}=18)$.

Sediment-trap samples analysed for their $\delta^{15} \mathrm{~N}$ signature were from 25 January to 5 February 2001, when the mass flux peaked (Fig. 9a), and from the peak pigment flux period, i.e. 23 March to 15 April 2001. The January samples $(\mathrm{n}=3)$ yielded an average $\delta^{15} \mathrm{~N}$ of $8.8 \pm 0.1(\mathrm{SD})$. The $\delta^{15} \mathrm{~N}$ values $(\mathrm{n}=3)$ of phytodetritus collected in the trap during the peak flux were much lower, with an average of $2.2 \pm 0.9$. We also analysed the $\delta^{15} \mathrm{~N}$ signature of the swimmers caught in the sediment trap during summer 2000. Amphipods had an average $\delta^{15} \mathrm{~N}$ of $10.0 \pm 0.6(\mathrm{n}=3$ samples with 100 individuals each) and copepods $10.2 \pm 0.1(\mathrm{n}=3$ samples with 100 individuals each).

\section{DISCUSSION}

\section{Particle supply to seafloor}

The goal of the ACES project was to collect new information on characteristic aspects of cold-water coral habitats in order to determine the key conditions for the occurrence of corals; one focus of ACES is the particle supply to coral communities and corals, including the origin and quality of the particulate material (G. Wolff: http://pcwww.liv.ac.uk/ocean/org_ geochem/aces.html).

Although data are accumulating through ACES and affiliated EU-projects (ECOMOUND, CORALMOUND), the published database is still relatively small. However, a substantial body of data on particle fluxes in Atlantic Ocean margin-habitats has been collected during 2 OMEX projects (van Weering \& McCave 2002), and one of the best-studied OMEX-sites in the vicinity of Galicia Bank is a $2200 \mathrm{~m}$ deep station ca. 75 miles east of Stn G100 (see Fig. 1). Vertical particle rain was measured at the OMEX site in moored sediment traps and concomitant measurements were made on the carbon consumption by the sediment community. Our ALBEX lander was deployed twice at the OMEX site, in June to September 1998 and in June to September 1999. The 2 deployments yielded a series of sediment oxygen consumption rates that fell in the narrow range of 0.5 to $1 \mathrm{mmolO}_{2} \mathrm{~m}^{-2} \mathrm{~d}^{-1}$ (average
$0.76 \mathrm{mmol}$ ), which is equivalent to an average carbon consumption of $2.8 \mathrm{mgC} \mathrm{m}^{-2} \mathrm{yr}^{-1}$. The oxygen consumption rates measured by us match the diffusive oxygen fluxes derived from in situ oxygen microprofiles (Epping et al. 2002). Vertical mass and POC fluxes at the OMEX site were measured by Antia \& Peinert (1999) from July 1998 to February 1999 using traps suspended at 600 and $1100 \mathrm{~m}$ depth. Extrapolation of their estimated average daily fluxes at $600 \mathrm{~m}$ yield an annual mass flux of $\sim 50 \mathrm{~g}$ dry wt $\mathrm{m}^{-2}$ and an organic $\mathrm{C}$ flux of $\sim 4.5 \mathrm{~g} \mathrm{~m}^{-2}$. Corresponding values for the $1100 \mathrm{~m}$ trap are $31 \mathrm{gdry} \mathrm{wt} \mathrm{m}^{-2}$ and $2.2 \mathrm{~g} \mathrm{C} \mathrm{m}^{-2}$.

Compared to the mid-water flux at the OMEX site, the near-bottom mass flux at Galicia Bank is relatively high. A major part $(60 \%)$ of the annual mass flux in 2000 at Galicia Bank was due to a single sample from late January to early February. Visual inspection showed that this particular sample consisted of sedimentary matter (foraminiferal ooze) that was probably resuspended from the seafloor by strong currents. We have no current measurements from 2000 to support this. However, in the 5 mo data from 2001, there was a significant correlation between the average current speed during the $11 \mathrm{~d}$ periods and the $\left(\log _{10}\right)$ mass flux $\left(r^{2}=0.52, p=0.007\right)$. This relation was strongly affected by 2 samples coinciding with relatively high current speeds. Therefore it seems that mainly in winter, resuspended sediment with low organic content occasionally enters the trap.

Despite the sometimes large quantity of resuspended sediment, the carbon flux in 2000 was primarily associated with the phytodetritus or pellet flux. Pellets accounted for $>96 \%$ of the chlorophyll $a$ in the trap samples, as shown by the chlorophyll a content of individual pellets $(0.03 \mu \mathrm{g})$. Linear regressions between fluxes of chlorophyll $a$ and $\mathrm{C}$ org, and between fluxes of pellets and C org, in 2000 were all significant $(\mathrm{p}<0.05)$. Pellets thus appear to have an important role in transferring phytodetritus and carbon to the coral community. This is further illustrated by the fact that in spring 2001, when only a few pellets were collected in the trap, both carbon and chlorophyll fluxes were considerably lower than in spring 2000 (Fig. 9b,d). We have no data to show if pellet production (grazing) or primary production was the limiting factor for the downward particle flux in 2001 or both. Our trap data nevertheless show there is a large year-to-year variation in the amount of carbon delivered to the coral community.

Interpretation of the trap data (for instance in relation to sediment carbon oxidation rates) is hampered by possible secondary (resuspension) flux of organic particles in our near-bottom trap. Current velocites on Galicia Bank daily exceed the critical speed required for resuspension of the typically-sized organic aggre- 
gates (10 to $15 \mathrm{~cm} \mathrm{~s}^{-1}$ at $1 \mathrm{~m}$, Thomsen et al. 2002). Whether particles are resuspended high enough off the bottom to be collected by our trap (at $3 \mathrm{~m}$ height above the bottom) is uncertain. According to Beaulieu (2003), resuspended aggregates are mostly advected very near the seabed (see also Thomsen \& van Weering 1998). Indications that phytodetritus did not re-enter the trap are the intact pellets in the trap samples: repeated contact with the sediment would have destroyed their integrity. Also, although the ratio chlorophyll a:phaeopigments in the trap samples decreased during spring 2000, as it would in ageing particles, the decrease was accompanied by a change in accessory pigments, pointing to a change in their source in the water column. Hence we infer that our C org flux data were not seriously confounded by resuspension.

The average carbon-oxidation rate by the sediment community on Galicia Bank in January to May 2001 was $7 \mathrm{mg} \mathrm{C} \mathrm{m}^{-2} \mathrm{~d}^{-1}$. However, the average daily $\mathrm{C}$ org flux in this period was more than double this value, viz. $17 \mathrm{mgC} \mathrm{m}^{-2} \mathrm{~d}^{-1}$. In the same period of 2000, carbon input was 5 -fold the spring 2001 oxidation rate, i.e. $37 \mathrm{mg} \mathrm{C} \mathrm{m}^{-2} \mathrm{~d}^{-1}$. Apparently there is a surplus of carbon which is not oxidised in the sediment. We hypothesise that, due to the relatively strong currents and the ensuing mobility of the sediment (see ripple marks in Fig. 3), part of the organic particles reaching the top of Galicia Bank is not entrained but is transported as bedload. The relative poverty of Galicia Bank sediments is clearly seen in comparisons between sediment biomass and carbon oxidation rates on Galicia Bank and those on other parts of the Iberian and NE Atlantic margin. In Fig. 11 we have plotted sediment carbon oxidation rates on Galicia Bank, the OMEX site and the Iberian abyssal plain (own unpubl. data). The line in Fig. 11 is from Epping et al. (2002) and depicts the model relationship between C-oxidation rates and depth on the Iberian margin. While rates for the $2200 \mathrm{~m}$ deep OMEX station are close to the predicted level, those for Galicia Bank fall far below the predicted level of slope sediments. Significant in this respect is that the rates on Galicia Bank and the OMEX site are similar despite the $1400 \mathrm{~m}$ difference in depth. The low carbon-oxidation (SCOC) rate at Galicia Bank is in line with findings of Flach et al. (2002) that macrofauna biomass on Galicia Bank is lower than at corresponding depths elsewhere on the NW Atlantic slope. Because macrofauna biomass and carbon-deposition flux are positively related in other parts of the Iberian margin (see Flach 2003), Flach et al. (2002) concluded that carbon input into the sediment of Galicia Bank is depressed. According to van Weering et al. (2002), the grain size and composition of sur-

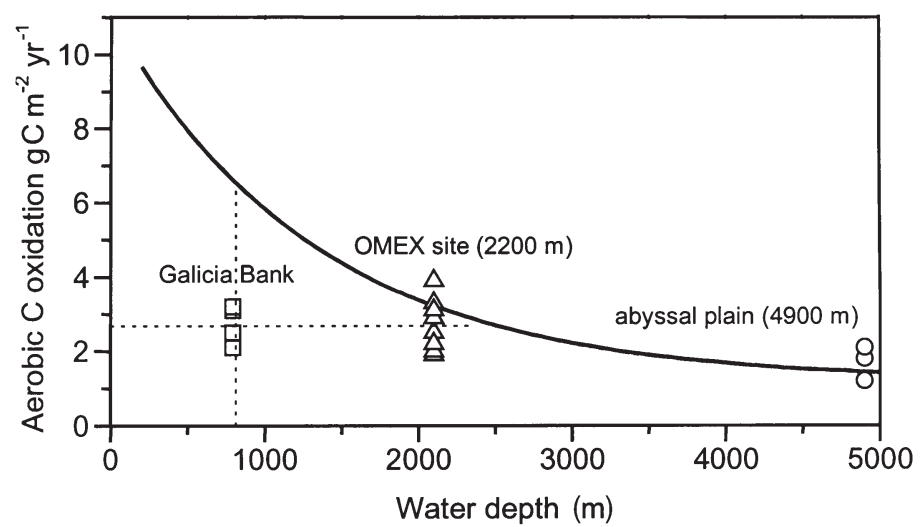

Fig. 11. Sediment carbon-oxidation rates calculated from in situ community oxygen consumption (SCOC) measured with ALBEX lander at the Galicia Bank $(770 \mathrm{~m})$, Ocean Margin Exchange (OMEX) station (2200 m) and Iberian abyssal plain (4900 m). Line depicts model relationship between sediment carbon oxidation and water depth on Iberian margin (Epping et al. 2002)

face sediment at Galicia Bank indicate winnowing of the fine sediment fraction. Conditions whereby finesediment and organic particles are not buried but transported instead to the vicinity of the seabed are favourable for filter- and interface-feeding organisms. The observations that sponges and ophiuroids are the dominant macrobenthos organisms on Galicia Bank (Flach et al. 2002), and that cold-water corals and crinoids dominate the local megafauna, support this.

\section{Isotope measurements}

In an attempt to determine the food source of the corals among the particles collected in the trap, we analysed $\delta^{15} \mathrm{~N}$ in coral tissue and trap material, and $\delta^{13} \mathrm{C}$ in coral tissue. The $\delta^{13} \mathrm{C}$ levels that we found in corals exclude the possibility that the coral community is methane-supported, since the various methane sources produce very distinctive $\delta^{13} \mathrm{C}$ values (Conway et al. 1994) that are far outside the values in coral tissue from Galicia Bank. Another food source that we considered was the phytodetrital particle rain caught in spring 2000. The mean $\delta^{15} \mathrm{~N}$ of phytodetritus that we collected in spring was $2.2 \%$. This value is within the range reported for phytoplankton collected in the upwelling zone off the Galician coast ( 2 to $6 \%$, Bode et al. 2003), albeit at the lower end. Possibly the higher part of the range represents $\delta^{15} \mathrm{~N}$ enrichment typical of upwelling due to enriched nitrate sources (Michener \& Schell 1994). The difference between the $\delta^{15} \mathrm{~N}$ of phytodetritus and coral tissue $(2.2$ and $9.5 \%$ respectively) spans 2 trophic levels (taking a mean enrichment of $\sim 3 \%$ per trophic level: Michener \& Schell 1994). This would imply that corals do not directly con- 
sume fresh phytodetritus, but possibly an intermediary trophic level. Obvious candidates for this level are the copepods and amphipods that we found in the trap, since Lophelia pertusa polyps have been observed to catch zooplankton (Hovland \& Mortensen 1999, p 19). The $\delta^{15} \mathrm{~N}$ values of all the crustaceans from the trap fall in a narrow range, with a mean close to $10 \%$. Clearly this value does not fit with the expected values between the $\delta^{15} \mathrm{~N}$ of phytodetritus and coral tissue. Moreover, the $\delta^{15} \mathrm{~N}$ value of $10 \%$ for the copepods in our samples lies above the range of values reported for zooplankton caught off NW Spain (Bode et al. 2003). We clearly did not find a clear-cut single food source of L. pertusa and Madrepora oculata. To assume that the corals assimilate a mixture of particles with different $\delta^{15} \mathrm{~N}$ signatures, e.g. phytodetritus and zooplankton (see Mortensen et al. 2001), would be speculative at this stage without additional observations and data on other tracers (e.g. lipids: Gooday et al. 2002). Solving this issue requires further sampling, although this is complicated by the fact that potential food particles must be collected near the corals since only a portion of particles in the upper water column reaches the seafloor.

\section{Relationship to substrate}

With the extensive cold-water coral reefs on the morainic hard bottom off Norway in mind, we were surprised to find isolated patches of Lophelia pertusa amidst the soft sediment on Galicia Bank. Records of $L$. pertusa growing in similar conditions are sparse. In a paper on the development of isolated L. pertusa patches, Wilson (1979) referred to Joubin (1922), who described isolated colonies from the Bay of Biscay separated by 'sables vaseuses' (muddy sand). Recently cold-water corals were found growing on the Darwin Mounds amidst and in close association with sediment waves (Masson et al. 2003). The surface of the Darwin Mounds is irregular and consists of small accumulations of coral fragments that act as nuclei for further coral growth. This situation is in line with the scheme of Wilson (1979), whereby he explains how larger coral structures or thickets develop. The Galicia Bank, however, appears to be a more extreme situation as we did not see any fragments on the sediment surface (Fig. 3) and the ripple pattern and trap data point to mobile sediment. We could, of course, not see if there was deeper subsurface coral rubble or other hard substrate that might be exposed when sediment waves migrate. However, in the absence of any visible hard substrate other than the colonies themselves, it is questionable if $L$. pertusa and Madrepora oculata are capable of expanding their numbers of colonies or recovering after fragmentation with such a high sediment load. It was equally surprising to find no corals on the eastern basalt peaks of Galicia Bank, although the bottomwater temperature at $600 \mathrm{~m}$ depth were still within the range tolerated by L. pertusa and M. oculata (Fig. 8). We have no explanation for this other than the suggestion that perhaps the smoothness or the mineralogy of the basaltic substrate is unsuitable for colonization (Kohler et al. 1999, Bavestrello et al. 2000). Colonization in the coral community will be dealt with in a separate paper (M.S.S.L. \& G.C.A.D. unpubl.) but in our opinion it is clear that the coral stands on Galicia Bank are a vulnerable ecosystem that requires protection as proposed by the World Wildlife Fund (T. F. Schmidt \& R. Garcia, www.ngo.grida.no/wwfneap/Publication/ briefings/GaliciaBank.pdf).

Acknowledgements. We are indebted to many people who helped us during the sometimes risky deployment of the landers: the captain, crew and technicians on board RV 'Pelagia', and particularly M. Laan, H. Franken, and T. Amaro. This study was supported by ACES contract EVK-CT-1999-00008.

\section{LITERATURE CITED}

Antia AN, Peinert R (1999) Particle flux at the Iberian margin. In: Wollast R (ed) Second Annual Science Report Ocean Margin Exchange OMEX-II-phase II. Universilé Libre de Bruxelles, Bruxelles, p 249-255

Bavestrello G, Bianchi CN, Calcinai B, Cattaneo-Vietti R, Cerrano C, Morri C, Puce S, Sara M (2000) Bio-mineralogy as a structuring factor for marine epibenthic communities. Mar Ecol Prog Ser 193:241-249

Beaulieu SE (2003) Resuspension of phytodetritus from the sea floor: a laboratory flume study. Limnol Oceanogr 48: 1235-1244

Bode A, Carrera P, Lens S (2003) The pelagic food web in the upwelling ecosystem of Galicia (NW Spain) during spring: natural abundance of stable carbon and nitrogen isotopes. ICES J Mar Sci 60:11-22

Conway NM, Kennicutt II MC, Dover CL (1994) Stable isotopes in the study of marine chemosynthetic-based ecosystems. In: K Lajtha, RH Michener (eds) Stable isotopes in ecology and environmental science. Blackwell, London, p 158-186

Epping E, van der Zee C, Soetaert K, Helder W (2002) On the oxidation and burial of organic carbon in sediments of the Iberian margin and Nazaré Canyon (NE Atlantic). Prog Oceanogr 52:399-431

Flach E (2003) Factors controlling soft bottom macrofauna along and across European continental margins. In: Wefer G, Billett D, Hebbeln D, Jørgensen BB, Schlüter M, van Weering TCR (eds) Ocean margin systems. SpringerVerlag, Berlin, p 351-363

Flach E, Muthumbi A, Heip, C (2002) Meio- and macrofauna community structure in relation to sediment composition at the Iberian margin. Prog Oceanogr 52:433-457

Fosså JH, Mortensen PB, Furevik DM (2002) The deep-water coral Lophelia pertusa in Norwegian waters: distribution and fishery impacts. Hydrobiologia 471:1-12

Frederiksen R, Jensen A, Westerberg H (1992) The distribution of the scleractinian coral Lophelia pertusa (Scleracti- 
naria) around the Faroe islands and the relation to internal tidal mixing. Sarsia 77:157-171

Freiwald A (2003) Reef-forming cold-water corals. In: Wefer G, Billett D, Hebbeln D, Jørgensen BB, Schlüter M, van Weering TCR (eds) Ocean margin systems. SpringerVerlag, Berlin, p 365-385

Freiwald A, Hühnerbach V, Lindberg B, Wilson J, Campbell J (2002) The Sula Reef Complex, Norwegian Shelf. Facies 47:179-200

Gooday AJ, Pond DW, Bowser SS (2002) Ecology and nutrition of the large agglutinated foraminiferan Bathysiphon capillare in the bathyal NE Atlantic: distribution within the sediment profile and lipid biomarker composition. Mar Ecol Prog Ser 45:69-82

Hovland M (1990) Do carbonate reefs form due to fluid seepage? Terra Nova 2:8-18

Hovland M, Mortensen PB (1999) Norske korallrev og processer I havbunnen. John Grieg Forlag, Bergen

Hovland M, Thomsen E (1997) Cold-water corals-are they hydrocarbon seep related? Mar Geol 137:159-164

Jeffrey SW, Vesk M (1997) Introduction to marine phytoplankton and their pigment signatures. In: Jeffrey SW, Mantoura RFC, Wright SW (eds) Phytoplankton pigments in Oceanography. Monographs on oceanographic methodology 10. UNESCO, Paris, p 37-84

Jensen A, Frederiksen R (1992) The fauna associated with the bank forming deep-water coral Lophelia pertusa (Scleractinaria) on the Faroe Shelf. Sarsia 77:53-63

Joubin L (1922) Les coreaux de mer profonde nuisibles aux chalutiers. Notes Mém Off Sci Tech Pêches Mar 18:1-16

Kohler J, Hansen PD, Wahl M (1999) Colonization patterns at the substratum-water interface: how does surface microtopography influence recruitment patterns of sessile organisms? Biofouling 14:237-248

Lavaleye MSS, Duineveld GCA, Berghuis EM, Witbaard R (2002) A comparison between the megafauna communities on the NW Iberian and Celtic continental marginseffects of coastal upwelling? Prog Oceanogr 52:459-476

LeDanois E (1948) Les profondeurs de la mer. Payot, Paris

Masson DG, Bett BJ, Billett DSM, Jacobs CL, Wheeler AJ, Wynn RB (2003) The origin of deep-water, coral-topped mounds in the northern Rockall Trough, Northeast Atlantic. Mar Geol 194:159-180

Meyerhoefer M (1994) Plankton pigments and their derivatives as biomarkers for the description and assessment of phytoplankton succession and sedimentation in the North Atlantic. Ber Inst Meeresk 251:1-188

Editorial responsibility: Otto Kinne (Editor), Oldendorf/Luhe, Germany
Michener RH, Schell DM (1994) Stable isotope ratios as tracers in marine aquatic food webs. In: Lajtha $\mathrm{K}$, Michener RH (eds) Stable isotopes in ecology and environmental science. Blackwell, London, p 138-157

Mortensen PB, Hovland M, Brattegard T, Farestveit R (1995) Deep water bioherms of the scleractinian coral Lophelia pertusa (L.) at $64^{\circ} \mathrm{N}$ on the Norwegian shelf: structure and associated megafauna. Sarsia 80:145-158

Mortensen PB, Hovland MT, Fossa JH, Furevik DM (2001) Distribution, abundance and size of Lophelia pertusa coral reefs in mid Norway in relation to seabed characteristics. J Mar Biol Assoc UK 81:581-597

Rogers A (1999) The biology of Lophelia pertusa (Linneaus 1758) and other deep-water reef-forming corals and impacts from human activities. Int Rev Ges Hydrobiol 84: 315-406

Smith KL Jr, Kaufmann RS, Baldwin RJ, Carlucci AF (2001) Pelagic-benthic coupling in the abyssal eastern North Pacific: an 8-year time-series study of food supply and demand. Limnol Oceanogr 46:543-556

Thomsen L, van Weering TCE (1998) Spatial and temporal variability of particulate matter in the benthic boundary layer at the N.W. European continental margin (Goban spur). Prog Oceanogr 42:61-76

Thomsen L, van Weering T, Gust G (2002) Processes in the benthic boundary layer at the Iberian continental margin and their implication for carbon mineralization. Prog Oceanogr 52:315-329

van Aken H (2000) The hydrography of the mid-latitude Northeast Atlantic Ocean. II. The intermediate water masses. Deep-Sea Res I 47:789-824

van Weering TCE, McCave IN (2002) Benthic processes and dynamics at the NW Iberian margin: an introduction. Prog Oceanogr 52:123-128

van Weering TCE, de Stigter HC, Boer W, de Haas H (2002) Recent sediment transport and accumulation on the NW Iberian margin. Prog Oceanogr 52:349-371

Wilson JB (1979) 'Patch' development of the deep-water coral Lophelia pertusa (L.) on Rockall Bank. J Mar Biol Assoc UK 59:165-177

Witbaard R, Duineveld GCA, van der Weele J, Berghuis EM, Reyss JP (2000) The benthic response to the seasonal deposition of phytopigments at the Porcupine abyssal plain in the North East Atlantic. J Sea Res 43:15-31

Zibrowius H (1980) Les scléractinaires de la Méditerranée et de l'Atlantique nord-oriental. Mém Inst Océanogr 11: $1-284$

Submitted: November 19, 2003; Accepted: April 6, 2004 Proofs received from author(s): July 23, 2004 